\title{
Artificial almond flavoring additive: A potential toxic compound for the environment
}

\author{
Aditivo aromatizante artificial de amêndoa: Um composto potencialmente tóxico para o meio \\ ambiente \\ Aditivo aromatizante de almendra artificial: Un compuesto potencialmente tóxico para el medio \\ ambiente
}

Received: 03/23/2021 | Reviewed: 04/01/2021 | Accept: 04/10/2021 | Published: 04/21/2021

\author{
Regiane da Silva Gonzalez \\ ORCID: https://orcid.org/0000-0003-0957-0125 \\ Federal Technological University of Paraná, Brazil \\ E-mail: regianegonzalez@gmail.com \\ Karoline Griebler Ribeiro \\ ORCID: https://orcid.org/0000-0001-7232-5822 \\ Federal Technological University of Paraná, Brazil \\ E-mail: karoline_griebler@hotmail.com \\ Amanda Almeida dos Santos \\ ORCID: https://orcid.org/0000-0003-1132-779X \\ Federal Technological University of Paraná, Brazil \\ E-mail: amanda.almeidaaa6@gmail.com \\ Flávia Vieira da Silva Medeiros \\ ORCID: https://orcid.org/0000-0001-6490-8876 \\ Federal Technological University of Paraná, Brazil \\ E-mail: flaviav@utfpr.edu.br \\ Débora Cristina de Souza \\ ORCID: https://orcid.org/0000-0001-6916-6330 \\ Federal Technological University of Paraná, Brazil \\ E-mail: dcsouza@gmail.com \\ Márcia Maria Mendes Marques \\ ORCID: https://orcid.org/0000-0001-7661-2570 \\ Federal Technological University of Paraná, Brazil \\ E-mail: marciammm2003@gmail.com \\ Ana Paula Peron \\ ORCID: https://orcid.org/0000-003-2598-2621 \\ Federal Technological University of Paraná, Brazil \\ E-mail: anaperon@utfpr.edu.br
}

\begin{abstract}
In this work, the chemical composition of the artificial almond flavoring was investigated, as well as the toxicity of this additive against bioassays commonly used to assess the environmental risk offered by chemical compounds and/or substances. The chemical identification detected ethanol (solvent), saccharin, benzaldehyde and benzoic acid. In L. sativa and A. cepa, concentrations of 100 and $10 \mu \mathrm{L} / \mathrm{L}$ flavoring caused a reduction in the germination rate and inhibition of root growth. In A. cepa, at 24 and 48 hours of exposure, concentrations 100 and $10 \mu \mathrm{L} / \mathrm{L}$ significantly reduced the division of root meristems, and concentrations 1 and $0.10 \mu \mathrm{L} / \mathrm{L}$ induced cellular changes and were aneugenic to plant meristems. The flavoring was highly toxic to A. salina with $\mathrm{LC}_{50}=0.082 \mathrm{ppm}$. Also, by partitioning into saturated solutions of octane and water, the commercial solution of the almond presented a log Kow of 1.37. Based on the results obtained, under the established analysis conditions, the flavoring was significantly phytotoxic, cytogenotoxic and toxic, and based on Kow it is estimated to have good stability in water and soil. These results indicate that almond flavoring is a potential environmentally toxic compound.
\end{abstract}

Keywords: Artificial flavoring; Reduction in germination potential; Reduction in cell division; Induction of cell changes; Aneugenic effect; Mortality; Stability in the environment.

\section{Resumo}

Neste trabalho, foi investigada a composição química do aromatizante artificial de amêndoa, bem como a toxicidade desse aditivo frente a bioensaios comumente utilizados para avaliar o risco ambiental oferecido por compostos e/ou substâncias químicas. A identificação química detectou etanol (solvente), sacarina, benzaldeído e ácido benzóico. Em L. sativa e A. cepa, concentrações de 100 e $10 \mu \mathrm{L} / \mathrm{L}$ de aromatização causaram redução na taxa de germinação e inibição do crescimento radicular. Em A. cepa, às 24 e 48 horas de exposição, as concentrações de 100 e $10 \mu \mathrm{L} / \mathrm{L}$ reduziram significativamente a divisão dos meristemas radiculares, e as concentrações de 1 e $0,10 \mu \mathrm{L} / \mathrm{L}$ induziram 
alterações celulares e foram aneugênicas aos meristemas das plantas. O aromatizante foi altamente tóxico para A. salina com CL50 = 0,082 ppm. Além disso, ao particionar em soluções saturadas de octano e água, a solução comercial da amêndoa apresentou um log Kow de 1,37. Com base nos resultados obtidos, nas condições de análise estabelecidas, o aromatizante foi significativamente fitotóxico, citogenotóxico e tóxico, e com base no Kow estima-se que tenha boa estabilidade na água e no solo. Esses resultados indicam que o aroma de amêndoa é um composto potencialmente tóxico para o meio ambiente.

Palavras-chave: Aromatizante artificial; Redução do potencial de germinação; Redução da divisão celular; Indução de alterações celulares; Efeito aneugênico; Mortalidade; Estabilidade no ambiente.

\section{Resumen}

En este trabajo se investigó la composición química del aromatizante artificial de almendras, así como la toxicidad de este aditivo frente a los bioensayos comúnmente utilizados para evaluar el riesgo ambiental que ofrecen los compuestos y/o sustancias químicas. La identificación química detectó etanol (solvente), sacarina, benzaldehído y ácido benzoico. En L. sativa y A. cepa, concentraciones de 100 y $10 \mu \mathrm{L} / \mathrm{L}$ de aromatización provocaron una reducción en la tasa de germinación e inhibición del crecimiento de las raíces. En A. cepa, a las 24 y 48 horas de exposición, concentraciones de 100 y $10 \mu \mathrm{L} / \mathrm{L}$ redujeron significativamente la división de los meristemas radiculares, y concentraciones de 1 y $0,10 \mu \mathrm{L} / \mathrm{L}$ indujeron cambios celulares y fueron aneugénicas para los meristemas de las plantas. El saborizante fue altamente tóxico para A. salina con LC50 = $0.082 \mathrm{ppm}$. Además, al dividir en soluciones saturadas de octano y agua, la solución comercial de almendras mostró un log Kow de 1,37. Con base en los resultados obtenidos, bajo las condiciones de análisis establecidas, el aromatizante fue significativamente fitotóxico, citogenotóxico y tóxico, y en base al Kow se estima que tiene buena estabilidad en agua y suelo. Estos resultados indican que el aroma de almendras es un compuesto potencialmente tóxico para el medio ambiente.

Palabras clave: Aroma artificial; Reducción del potencial germinativo; Reducción de la división celular; Inducción de cambios celulares; Efecto aneugénico; Mortalidad, Estabilidad en el medio.

\section{Introduction}

Flavoring additives are produced on a large scale worldwide. Only in 2018, the market for these substances was valued at US \$ 28.2 billion, with an estimated annual growth of 7\% until 2021 (Ramesh \& Muthuraman, 2018; Leffingwell \& Associates, 2020). Artificial flavorings or those obtained by synthesis in the laboratory are the most used in developing countries, such as Brazil, due to the low cost of obtaining them, due to their significant commercialization and the efficiency offered in the aromatization of different products (Bom et al., 2019).

Among the widely produced additives is the artificial almond flavoring. In Brazil this additive is a leader in synthesis for giving taste and aroma to sweet and savory processed foods, such as sauces, pasta, meat, savory snacks, soft drinks, beers, chocolates, ice cream, jams, oils, among other foods, and because it is used as excipient in various classes of drugs (Bencsik et al., 2018). In the scientific literature, the benzaldehyde is usually the main substance responsible for the artificial aroma and taste of almond (Gholivand \& Ahmadi 2008). However, manufacturing companies do not report the detailed chemical composition of their flavoring additives on labels and commercial websites.

Aroma and taste additives are released for use by the food safety agencies Food and Agriculture Organization (FAO 2006) and International Flavor and Fragrances (IFF 2017), and nationally by the National Health Surveillance Agency (ANVISA) (Brasil, 2007). There are differences between regulatory agencies and health professionals regarding the safety in the use of these products (Amchova, Kototoya \& Ruda-Kuroda, 2015; Sales et al., 2017). However, in addition to the issues related to human health in the use of these additives, there is the environmental issue.

Unlike the industries of other additives, considered as emerging pollutants, such as artificial colorings and sweeteners, the flavoring industry is rarely associated with negative impacts on the environment (Silva et al., 2020). Nevertheless, the taste and aroma production sector generates a significant volume of effluents and waste every year (Teaf, Teaf \& Covert, 2015; Silva et al., 2020). In general, biological degradation is the conventional method for effluent treatment most used by the manufacturing industries of artificial flavorings, such as the almond additive. Due to the widespread need for production and 
with the retention times applied to biological degradation, this treatment is not fully effective in the degradation of these substances (IFF, 2017).

Indeed, manufacturing companies recognize that part of the flavorings produced, in their intact chemical composition, persist in the final effluent that will be released into water resources and/or the public sewer network, and declare that other degradation processes, such as advanced oxidative processes, should be considered/evaluated for a more efficient degradation of the generated waste (Leffingwell \& Associates, 2019). However, they emphasize that the concentrations of flavorings in the effluents after biological degradation are low and not harmful to the environment, but do not inform the levels. In addition, the artificial almond flavoring is not totally degraded by the human digestive tract, and human feces and urine are important ways of introducing this additive in aquatic environments (Leffingwell \& Associates, 2019; Industryarc, 2021).

It is important to highlight that although the present study has focused on the almond flavoring, there is no information in the literature about the toxicity caused to the environment by aroma and taste additives in general, as well as the potential for accumulation and persistence of these in the soil and in water resources.

Vascular plants are recommended by the US Environmental Protection Agency as test organisms for the assessment and monitoring of contaminants in different environmental matrices (Herrero et al., 2012; Mendes et al., 2021). Lactuca sativa L. (lettuce) and Allium cepa L. stand out for phytotoxicity assessment tests, which can evaluate the germination potential of their seeds and the growth and development of their roots in the presence of chemical compounds or substances of interest (Zhao et al., 2016; Mendes et al., 2021).

Still, among the plant tests internationally used in the evaluation of cytotoxicity and genotoxicity is the bioassay in root meristem cells of A. сера. These tissues are routinely used to determine the toxic effects at the cellular level of compounds and/or substances present in the environment (Tabrez et al., 2011; Herrero et al., 2012). Biomarkers used in this assay are the mitotic index (cell division index) for assessing different levels of cytotoxicity, and the frequency of chromosomal changes and mitotic spindle for the assessment of genotoxicity (Matos et al., 2017; Sales et al., 2018). The results observed through the $A$. cepa system have an important correlation with results obtained in animals and cell cultures (Marques et al., 2015; Sales et al., 2017; Mendes et al., 2020).

As an animal model, A. salina nauplii are test organisms with high sensitivity and used worldwide to assess the toxicity of pollutants from natural waters, industrial and domestic effluents and substances in general (Meyer et al., 1982; Rocha et al., 2018). They have a short life cycle, high population densities, good adaptation to adverse environmental conditions, high fertility, reproduction by parthenogenesis, reduced body size and are consumers of a wide variety of nutrients, characterized as non-selective filter feeding (Silva et al., 2020; Mendes et al., 2020). In addition to a cosmopolitan distribution and high population densities, these microcrustaceans are food for different organisms (Rosa et al., 2016).

Another important factor about substances present in effluents is their interaction with the environment, which can be estimated by octanol-water partition tests (Kow). Based on this quantification, it is possible to establish the preferred solubility of what is evaluated in aqueous and organic media, and to define its stability in different environmental matrices (Borrirukwisitsak, Keender \& Gauchotte-Lindsay, 2012).

Based on the context, the objectives of this study were to determine the chemical composition of artificial almond flavoring, to evaluate the ability of this additive to cause phytotoxicity to L. sativa and A. cepa, cytotoxicity and genotoxicity to A. cepa, toxicity to A. salina, and estimate, through Kow, its stability in soil and water. 


\section{Methodology}

This research was developed at the Federal Technological University of Paraná. Campo Mourão Campus. The scientific methodology on which the present study was based was the descriptive methodology, according to Koche (2011) and Ludke and Andre (2013).

\subsection{Obtaining the aroma and taste additive, flavoring solution and commercial information on the chemical composition}

The artificial almond flavoring was purchased from a large company, specialized in the manufacture and commercialization of national and international flavoring additives for use on an industrial scale, located in the city of São Paulo, state of São Paulo, Brazil.

The flavoring solution was stored in an amber bottle, properly sealed, was yellowish, had a neutral $\mathrm{pH}$ and was within the expiration date. On the product label, information on the chemical composition of flavorings was: consisting of aroma and taste promoting/enhancing agents, sweetener, preservative and dispersant, and ethanol.

\subsection{Chemical identification of the flavoring solution}

For the identification of functional groups indicating substances present in the almond additive, the following methodologies were used based on color change of the flavoring solution tested after mixing $1 \mathrm{~mL}$ test solution with $0.5 \mathrm{~mL}$ almond additive solution for each analysis performed.

(i) Jones Test - identifies the presence of primary and secondary alcohols when the initially yellow-orange solution turns a bluish-green color due to the oxidation reaction of chromate ions.

(ii) Lucas Test - identifies the presence of secondary or tertiary alcohols through the formation of precipitate or phase separation.

(iii) Fehling and Benedict Test - identifies the presence of non-phenolic aldehydes, or reducing sugars, by means of a brown precipitate confirming the formation of carboxylic acid.

(iv) Tollens Test - identifies the presence of aldehyde by the creation of a silver mirror in the reaction test tube.

(v) Ferric chloride Test - identifies the presence of phenol by the formation of colored complexes (reddish blue).

(vi) Bayer Test - identifies the presence of unsaturation by discoloration of a purple solution. It can also indicate the presence of primary or secondary alcohols as well as aldehyde.

(vii) Ferrous hydroxide - identifies the presence of nitrogen functions by the formation of brown precipitate.

\subsection{Spectrophotometric evaluation of the flavoring solution}

An aliquot of $1 \mathrm{~mL}$ almond flavoring was extracted by silica gel column chromatography. The separation of the compounds present in flavoring was carried out by extraction in test tubes by diluting $20 \mathrm{~mL}$ of the following sequence of solvent fractions: $100 \%(\mathrm{v} / \mathrm{v})$ hexane, acetate/hexane mixture $(10,20,30,40,60,80 \%(\mathrm{v} / \mathrm{v})), 100 \%(\mathrm{v} / \mathrm{v})$ acetate, 50\% (v/v) methanol/acetate, $100 \%(\mathrm{v} / \mathrm{v})$ methanol.

After extraction, samples were placed in an oven at $50^{\circ} \mathrm{C}$ until solvent evaporation, and the amount of sample in each extraction was then measured. For spectrophotometric evaluation, $1.5 \mathrm{~mL}$ methanol PA was added to each fraction of sample extracted, with each sample homogenized and evaluated between 200 and 600nm. 


\subsection{Definition and preparation of flavoring concentrations for evaluation in different bioassays}

Due to the scarcity of studies in the scientific literature on the toxicity of almond flavoring that could serve as a basis for establishing the concentrations to be evaluated in the present study - and considering that the concentration of additives characterized as emerging pollutants in environmental matrices, such as dyes, are usually found in the $\mu \mathrm{L}$ or $\mu \mathrm{g}$ scale - it was established to evaluate the flavoring additive in phytotoxicity bioassays in L. sativa and A. cepa and cytogenotoxicity in A. cepa at concentrations 100, 10, 1, 0.10 and $0.01 \mu \mathrm{L} / \mathrm{L}$. For toxicity assessment in A. salina nauplii, the established concentrations were $100,50,25,12.50,6.25,3.12,1.56,0.78,0.39,0.19$ and $0.01 \mu \mathrm{L} / \mathrm{L}$.

Distilled water was used to prepare the concentrations as a negative control. Water was distilled the day before the experiments and stored in autoclaved amber bottles. The preparation of solutions and root treatments of onion bulbs and nauplii of A. salina were carried out in the morning, without the presence of artificial light and with reduced natural light. The $\mathrm{pH}$ of the solutions was maintained at 7.0.

\subsection{Analysis of the germination potential of seeds and the relative growth index of L. sativa and A. cepa roots}

Seeds of L. sativa (Isla ${ }^{\circledR}$, monica variety) and A. cepa (Casa das Sementes ${ }^{\circledR}$, baia periforme variety) were obtained from an agricultural farm and were free of pesticides. According to information on the packages, germination rate of samples from the lettuce seed lot was $99 \%$, while from the onion seed lot, $98 \%$. In the whole experiment, seeds from the same batch were used. Tests were performed in $100 \times 15 \mathrm{~mm}$ glass Petri dishes, previously sterilized in an autoclave. Two sheets of Whatman \#3 filter paper were placed on each dish to serve as a support for the seeds.

In the choice of seeds for calculating the Germination Rate (GR) and for the Relative Root Growth Index (ICR), undamaged and similar sized seeds were separated with the aid of a stereoscopic magnifying glass, which were placed on filter papers. All concentration, for the two tests, was analyzed in quintuplicate, and for each dish 10 seeds were used, distributed over filter papers at similar distances. Distilled water was used as a negative control.

In all dishes, $5 \mathrm{~mL}$ flavoring concentration were placed. Dishes were incubated in a BOD germination chamber, under a 12-hour photoperiod, at $24 \pm 1^{\circ} \mathrm{C}$ for seven days $(24,48,72,144,288,312$ and 336 hours). Every 24 hours, at the same time, we counted the total number of germinated seeds in each dish, and for each concentration and specific exposure time (day), we calculated the Germination Rate (GR) as follows: GR = (Number of seeds germinated in each concentration)/(Number of seeds germinated in the negative control) $\mathrm{x} 100$.

Also, on the seventh day of the experiment, five germinated seeds were randomly collected from each dish and the length of their roots was measured using a caliper. For all concentrations, root lengths were averaged and divided by five (number of repetitions). Then, the ICR was calculated using the following formula: (Average root length in each treatment)/(Average root length of the control).

The ICR values were distinguished in three categories, according to Biruk et al. (2017): root growth inhibition (I): 0 $<\mathrm{x}<0.8$; no significant treatment effect (SES): $0.8 \leq \mathrm{x} \leq 1.2$; and significant treatment effect (E): $\mathrm{x} \geq 1.2$.

The phytotoxic potential was determined based on the significant results of seed germination inhibition and/or root elongation reduction in the two species considered.

\subsection{Cytotoxicity and genotoxicity test in $A$. cepa root meristems}

Onion (beta crystal variety, from an organic garden) bulbs were placed in containers with distilled water, constantly aerated, and germinated in environments with no light until roots of $2.0 \mathrm{~cm}$ in length were obtained. To analyze each flavoring concentration, an experimental group with five onion bulbs was established. Before putting the roots in contact with their 
respective treatments, some roots were collected and fixed to serve as control of the bulb itself, which was identified as analysis time 0 hour or control of the bulb itself.

Then, the remaining roots of each bulb were placed in their respective treatments for 24 and 48 hours, procedures called exposure times 24 and 48 hours, where roots were collected every 24 hours. Every 24 hours a new solution for each flavoring concentration was prepared to replace the previous day's solution. A negative control was prepared with distilled water only. Distilled water was used as a negative control. A positive control was prepared with methyl methanesulfonate (MMS), a substance known to be cytotoxic and genotoxic to the A. cepa test system at $4 \times 10^{-4} \mathrm{~mol} / \mathrm{L}$. The collected roots were fixed in Carnoy 3: 1 solution (ethanol: acetic acid) for up to 24 hours.

Slides were mounted according to the protocol proposed by Guerra and Souza (2002) and analyzed under an optical microscope with a 40X objective lens. For each bulb, 1000 cells were evaluated, totaling 5000 cells for each control group (0 hours), each group exposure time 24 hours and each group exposure time 48 hours, adding up to 15000 cells analyzed for all concentration of flavoring.

Cells in interphase, prophase, metaphase, anaphase and telophase were counted, and the mitotic index was calculated to determine the cytotoxic potential. The mitotic index or cell division index was calculated as follows: (Total number of dividing cells/Total number of cells analyzed) x 100. Genotoxic potential was evaluated using the frequency of micronuclei, colchicine metaphases, anaphase and telophase bridges, gene amplifications, cells with adhesions, nuclear buds, and multipolar anaphases, among other changes.

The results obtained in A. cepa were subjected to analysis of variance (ANOVA) and the observed means were compared using the Scott-Knott test $(\mathrm{p}<0.05)$, with the aid of the free software BioEstat ${ }^{\circledR}$.

\subsection{Toxicity test in $A$. salina nauplii}

A. salina cysts were incubated in salted water, in a glass container, previously autoclaved, equipped with a dark compartment and another with artificial lighting. Saline water was kept at room temperature, under constant agitation and aeration, for of 48 hours, until the larvae hatched. Sea salt was obtained from a health food store.

The nauplii were collected, rinsed with freshwater, counted by sight $(n=10)$ using a Pasteur pipette and transferred to test tubes containing $3 \mathrm{~mL}$ each concentration. The control was prepared with salted water only. All concentrations were analyzed in quintuplicate, and the number of dead individuals were counted after 24 hours of exposure, considering dead those which did not move during ten seconds of observation, nor with the slight agitation of the bottle.

The percentage mortality was calculated from the total number of dead nauplii for each concentration. Data are expressed as mean \pm standard deviation. The concentration that caused mortality of $50 \%$ larvae $\left(\mathrm{LC}_{50}\right)$ was calculated based from the linear equation by taking the antilogarithm. The toxicity of the almond flavoring was classified according by Himri et al. (2013) as follows: $\mathrm{LC}_{50}>100$ ppm- non toxicity; $\mathrm{LC}_{50}>30$ and $<100$ ppm- mildly toxic; $\mathrm{LC}_{50} 10-30$ ppm- moderately toxic; $\mathrm{LC}_{50} 1-10 \mathrm{ppm}$ - toxic; $\mathrm{LC}_{50}<1 \mathrm{ppm}$ - highly toxic.

\subsection{Determination of the octanol/water partition coefficient (Kow)}

A $0.8 \mathrm{~mL}$ aliquot of almond flavoring was added to $8 \mathrm{~mL}$ saturated octanol/water $(50 \% \mathrm{~V} / \mathrm{V})$ mixture. Then, the obtained solution was manually stirred for 10 seconds and then vortexed for 2 minutes, and then left to stand for 24 hours for spectrophotometric evaluation of each phase.

A calibration curve obtained from the dilution of a solution of known concentration (octanol or water, saturated) was used. Each dilution was then evaluated spectrophotometrically at $\mathrm{x}$ and $\mathrm{y} \mathrm{nm}$ to quantify the compounds present in the almond 
flavoring. The determination of Kow was performed from the ratio of the concentration of the flavoring in the organic phase to its concentration in the aqueous phase.

\section{Results and Discussion}

\subsection{Chemical and spectrotometric analysis of almond flavoring.}

Table 1 describes the main groups of compounds, and the tests used, present in the almond flavoring. Based on the results of this table, regarding the chemical analysis of the almond flavoring, it was possible to observe the presence of alcohols, and to distinguish between primary, secondary and tertiary alcohols. While the Jones test evidenced the presence of oxidizable groups, such as alcohols (primary and secondary) and aldehyde, in the Lucas test, the primary alcohols do not react. With this, it was possible to establish the presence of ethanol, confirming the information stated on the label of the almond flavoring bottle. In addition, it was possible to rule out the presence of secondary and tertiary alcohols, and through the ferric chloride test, the absence of phenols was verified.

Table 1. Identification of functional groups indicating substances present in the artificial almond additive.

\begin{tabular}{cccccccc}
\hline $\begin{array}{c}\text { Substances/Methodology } \\
\text { ofidentification }\end{array}$ & Jones & Lucas & $\begin{array}{c}\text { Fehling/ } \\
\text { Benedict }\end{array}$ & Tollens & $\begin{array}{c}\text { Ferricchl } \\
\text { oride }\end{array}$ & Bayer & Fe(OH) 2 \\
\hline Almond Flavoring & + & - & - & + & - & + & + \\
Ethanol PA & + & - & - & - & - & - & - \\
Terc Butanol & - & + & - & - & - & - & - \\
Dionized water & - & - & - & - & - & - & - \\
Sugarcane (Saccharose) & + & - & - & - & - & - & - \\
Salicylic Acid PA & + & + & - & - & - & - & - \\
Benzaldehyde PA & + & - & - & + & - & + & + \\
Acetone PA & - & - & - & - & - & & + \\
\hline
\end{tabular}

Source: Authors.

The ferrous hydroxide test indicated the presence of nitrogen compounds, possibly saccharin. Using the Bayer test, the presence of unsaturated compounds was found, which indicates the presence of aromatic compounds. The presence of aldehyde was observed by the Tollens test, whose presence can be confirmed by the evaluation of a sample of benzaldehyde (PA). It was verified by the Fehling and Benedict test that the aldehyde was benzyl, proving the presence of benzaldehyde in the flavoring, and corroborating the literature on this compound being the responsible for the aroma and flavor of almonds in artificial flavorings.

Figure 1 shows the spectral changes in the UV / Vis region to almond flavor in differents methanol solution concentration and Spectral changes in the UV/Vis region to almond flavor extracted in by column chromatography. Table 2 shows the Mass fractions of almond flavor extracted in different fractions of solvent. Based on the spectrophotometric evaluation (Figure 1B) and the determination of the extracted masses as a function of the solvent fraction used (Table 2), it is possible to observe the extraction of three distinct fractions of compounds in the samples. Considering the polarity sequence of the solvent mixture used (Table 2) and correlating these data with the identification of functional groups (Table 1), it was found that the compounds extracted were saccharin, benzaldehyde and benzoic acid. 
Figure 1. (A) Spectral changes in the UV / Vis region to almond flavor in differents methanol solution concentration. (B) Spectral changes in the UV / Vis region to almond flavor extracted in by column chromatography.

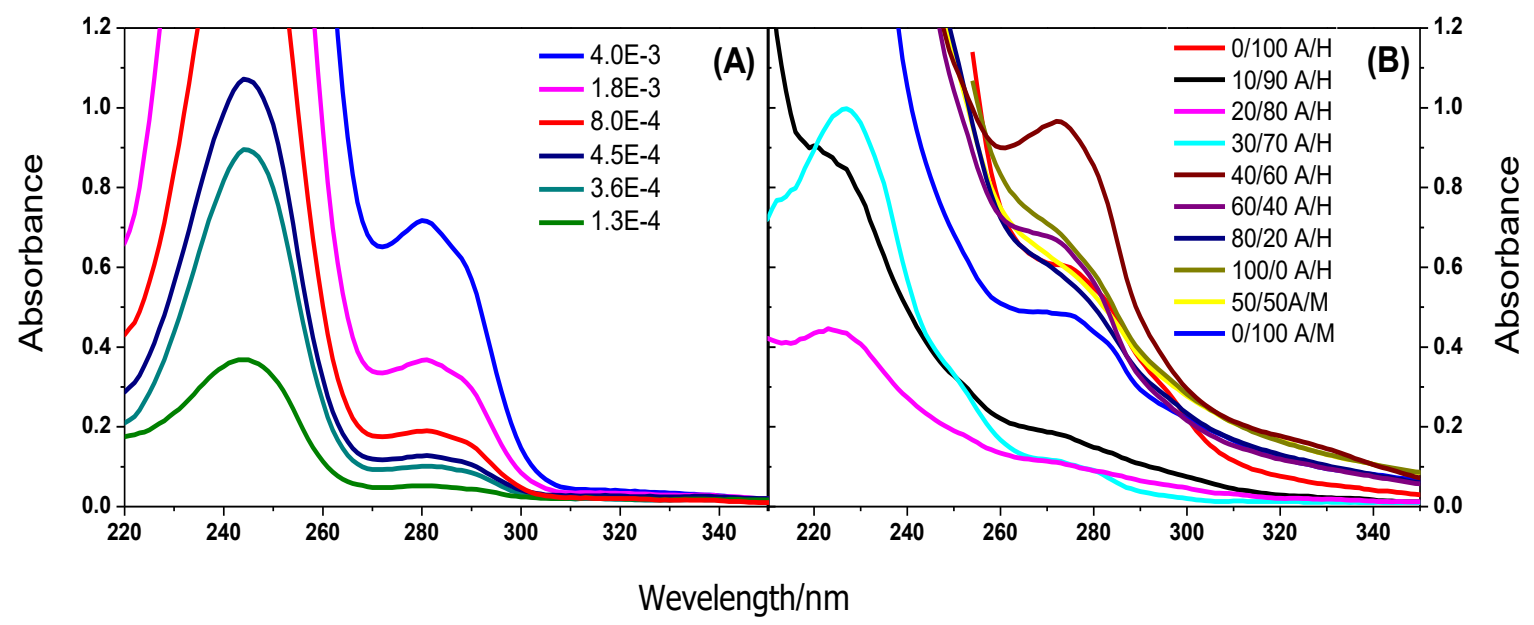

Source: Authors.

Table 2. Mass fractions of almond flavor extracted in different fractions of solvent.

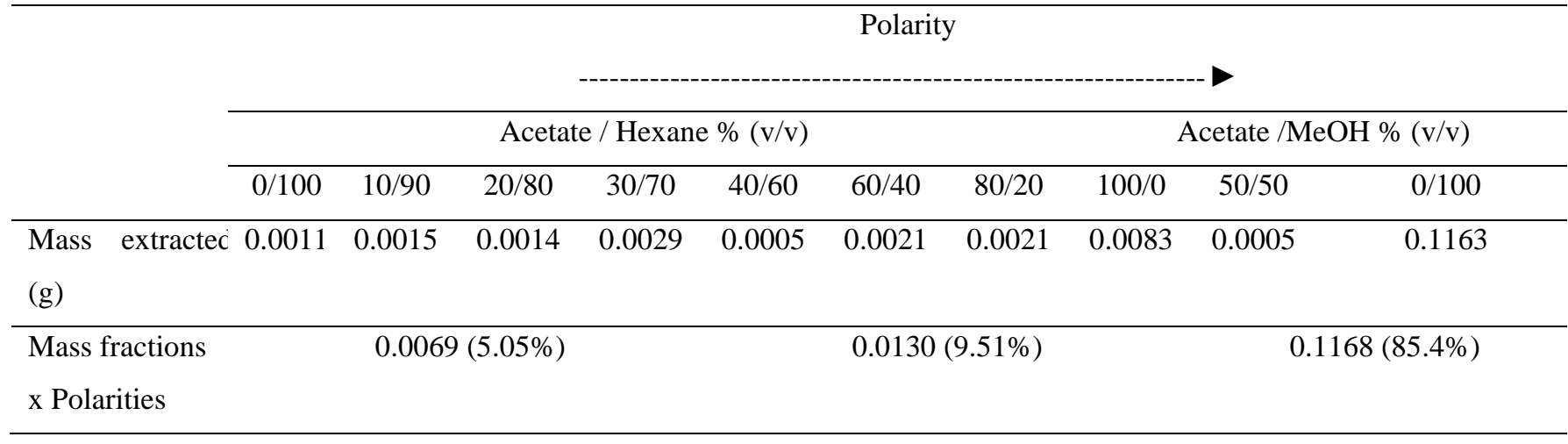

Source: Authors.

Figure 2 characterizes the spectral changes for the almond flavor extracted by column chromatography for different fractions of the solvent. In the first fraction extracted (Figure $2 \mathrm{~A}$ ), it was found that the first three spectra correspond to the same compound extracted and are similar to saccharin $\left(\square_{\max }=267 \mathrm{~nm}\right.$ ), which corroborates the identification of functional groups for nitrogen compounds. When evaluating the curves referring to the 20/80 and 30/70 A/H extractions, a maximum absorption shift for less energetic levels was observed for 30/70, as well as an inversion in the absorption ratio between the peaks, indicating the extraction of a different compound. 
Figure 2. Spectral changes in the UV / Vis region to almond flavor extracted by column chromatography for different solvent fractions.

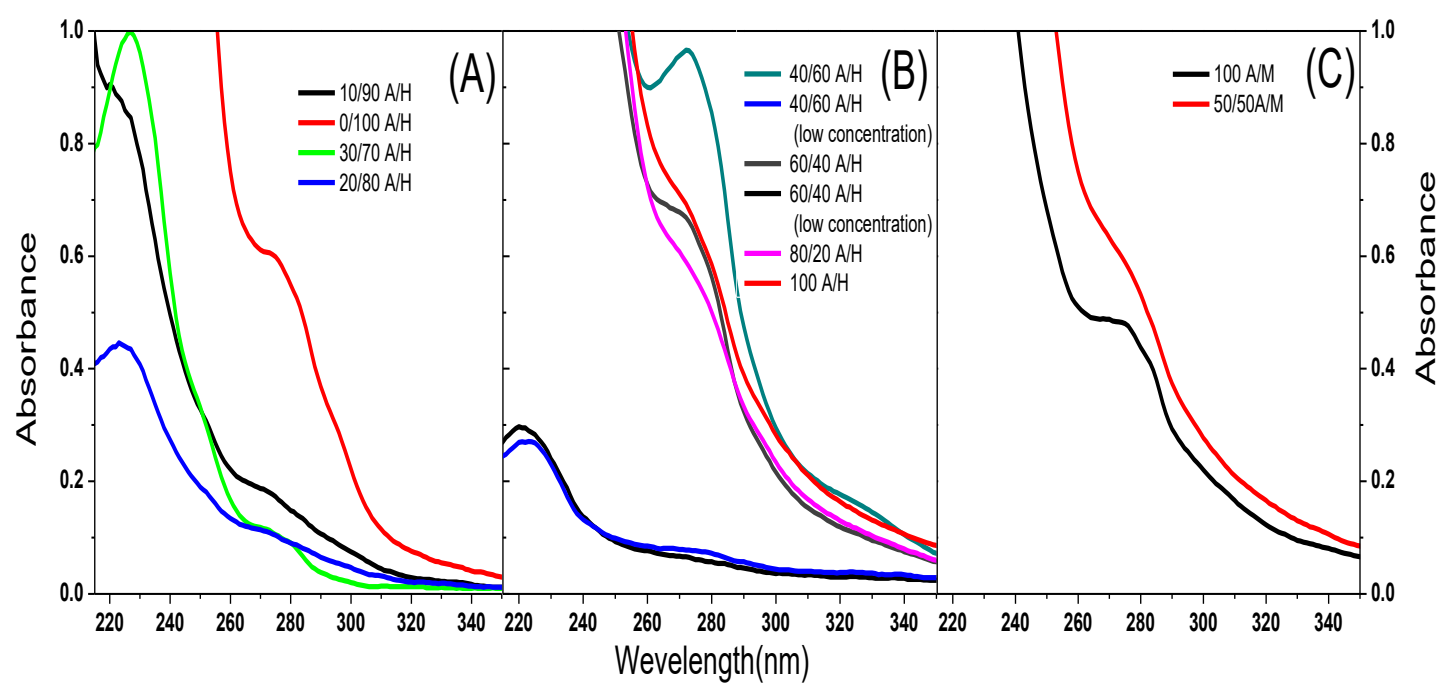

Source: Authors.

Regarding the second fraction extracted (Figure 2B), it is possible to observe, only for the 40/60 A/H extraction, the existence of a signal at $325 \mathrm{~nm}$, and at $272 \mathrm{~nm}$ a more defined signal compared to the $100 / 0 \mathrm{~A} / \mathrm{H}$ extraction that demonstrated a slight inflection, indicating distinct compounds. Furthermore, with respect to this same figure, the spectral curves referring to extractions 40/60 and 60/40 performed after dilution showed a gentle inversion in the intensity of the peaks at 220 and $272 \mathrm{~nm}$.

The profile of the $80 / 20$ and 100/0 A/H curves are different from the curves obtained with a lower acetate fraction, which demonstrates that the increase in solvent polarity favors the extraction of a more polar compound at the expense of a compound with lower polarity. With the extraction performed using solvents of higher polarity (Figure 2C) despite the greater amount of compound extracted, no signal was verified in the region of $325 \mathrm{~nm}$, which proved to be benzoic acid, of greater polarity compared to benzaldehyde.

Based on Figures 1 and 2, in the first fraction extracted, the spectrum corresponding to the extraction using 10/90 (A/H) is similar to the sucrose spectrum. The spectra referring to extraction with $100 \% \mathrm{H}, 10 / 90 \mathrm{~A} / \mathrm{H}$ and $20 / 80 \mathrm{~A} / \mathrm{H}$ correspond to the same extracted compound. However, when evaluating the curves referring to the 20/80 and 30/70 A/H extractions, a shift in the maximum absorption length close to $225 \mathrm{~nm}$ can be observed for less energetic levels, indicating the presence of more than one type of molecule.

Still, the 20/80 spectrum shows less absorption at 230nm when compared to the 30/70. When evaluating the spectra referring to the second fraction extracted, a signal was observed at $325 \mathrm{~nm}$ region for the $40 / 60$ extraction, in addition to presenting a more intense and defined signal at $272 \mathrm{~nm}$ when compared to the 100/0 $\mathrm{A} / \mathrm{H}$ extraction, which shows only a curve in this region of the spectrum. This again demonstrates the presence of more than one type of compound present in the extraction.

The spectral curves for 40/60 and 60/40 extractions performed after dilution showed a slight inversion in peak intensity at 220 and $272 \mathrm{~nm}$. It was also observed that the profile of the 80/20 and 100/0 A/H curves are different from the curves obtained with a lower fraction of acetate, which demonstrates that the increase in the solvent polarity and allowing the extraction of a more polar compound in detriment to a compound with lower polarity. With the extraction carried out using 
solvents of greater polarity it was possible to obtain a greater amount of extracted compound, and the absence of signal at 325 $\mathrm{nm}$. Based on the information given, it is reiterated that the formulation of the flavoring evaluated consists of ethanol, saccharin, benzaldehyde and benzoic acid.

\subsection{Toxicity analyzes of almond flavoring}

Table 3 shows the percentage (\%) of germinated seeds of L. sativa and A. cepa exposed to different concentrations of artificial almond flavoring. According to this table, L. sativa seeds subjected to concentrations of 100 to $0.10 \mathrm{uL} / \mathrm{L}$ germinated only on the fourth day of analysis, unlike the control and $0.01 \mathrm{uL} / \mathrm{L}$ concentration, where seeds germinated up in the first 24 hours of the experiment. In A. сера, for all concentrations and for the negative control, germinated seeds were observed only after the fourth day of analysis. This condition is normal for lettuce seeds of the baia periforme variety, since the seed packaging informed that germination would occur from the third or fourth day after planting.

Table 3. Mean percentage (\%) of germinated seeds of L. sativa and A. cepa exposed to different concentrations of the artificial almond flavoring for five consecutive days.

\begin{tabular}{|c|c|c|c|c|c|c|c|}
\hline \multicolumn{8}{|c|}{ Taxa de germinação em L. sativa (\%) } \\
\hline $\begin{array}{c}\text { Concentração } \\
(\mu \mathrm{L} / \mathrm{L}) / \mathrm{TE} \text { (dias) }\end{array}$ & 1 & 2 & 3 & 4 & 5 & 6 & 7 \\
\hline 100 & 0 & 0 & 0 & 20 & 30 & 30 & 30 \\
\hline 10 & 0 & 0 & 0 & 23 & 27 & 27 & 27 \\
\hline 1 & 0 & 0 & 0 & 30 & 40 & 40 & 43 \\
\hline 0.10 & 0 & 0 & 0 & 90 & 90 & 90 & 90 \\
\hline 0.01 & 50 & 100 & 100 & 100 & 100 & 100 & 100 \\
\hline $\mathrm{NC}$ & 60 & 100 & 100 & 100 & 100 & 100 & 100 \\
\hline \multicolumn{8}{|c|}{ Taxa de germinação em A. сера $(\%)$} \\
\hline $\begin{array}{c}\text { Concentração } \\
(\mu \mathrm{L} / \mathrm{L}) / \mathrm{TE} \text { (dias) }\end{array}$ & 1 & 2 & 3 & 4 & 5 & 6 & 7 \\
\hline 100 & 0 & 0 & 0 & 10 & 20 & 20 & 27 \\
\hline 10 & 0 & 0 & 0 & 20 & 20 & 27 & 27 \\
\hline 1 & 0 & 0 & 0 & 20 & 30 & 37 & 37 \\
\hline 0.10 & 0 & 0 & 0 & 60 & 90 & 90 & 90 \\
\hline 0.01 & 0 & 0 & 0 & 100 & 100 & 100 & 100 \\
\hline $\mathrm{NC}$ & 0 & 0 & 0 & 100 & 100 & 100 & 100 \\
\hline
\end{tabular}

ET - Exposure Time, NC - Negative Control. Source: Authors.

In addition, considering the seventh day of analysis, concentrations 100 to $0.10 \mu \mathrm{L} / \mathrm{L}$ of the flavoring significantly reduced - less than $50 \%$ - the germination rate of A. cepa and L. sativa seeds when compared to the results obtained for the negative control. The results obtained for the concentration $0.01 \mathrm{uL} / \mathrm{L}$ were not toxic to the seeds of both species.

Table 4 shows the Relative root growth index (ICR) of roots subjected to different concentrations of the artificial almond flavoring. Based on the results, concentrations of 100 to $0.10 \mu \mathrm{L} / \mathrm{L}$ inhibited root growth in the two species considered, with ICR $0<\mathrm{x}<0.8$ proving to be phytotoxic to roots of L. sativa and A. cepa. 
Table 4. Relative root growth index (ICR) of roots subjected to different concentrations of the artificial almond flavoring for seven days.

\begin{tabular}{ccc}
\hline $\begin{array}{c}\text { Concentration } \\
\mathrm{uL} / \mathrm{L}\end{array}$ & ICR L. sativa & ICR A. cepa \\
\hline 100 & 0.38 & 0.55 \\
10 & 0.45 & 0.56 \\
1 & 0.55 & 0.69 \\
0.10 & 0.59 & 0.79 \\
0.01 & 1.02 & 1.32 \\
$\mathrm{NC}$ & - & - \\
\hline
\end{tabular}

NC - negative control. Source: Authors.

It is important to mention that the roots obtained by exposing L. sativa and A. cepa seeds to different concentrations of the almond additive, including the $0.01 \mu \mathrm{L} / \mathrm{L}$ concentration that did not cause phytotoxicity, were very thin, hindering the delimitation of their meristematic regions. The tests for both species were performed more than once and, in the same way, the same characteristics were obtained for the roots. It is suggested that this condition is also a result of phytotoxicity of the flavoring to L. sativa and A. cepa. Furthermore, based on was informed, it is justified not to perform the cytotoxicity and genotoxicity tests of the flavoring for L. sativa.

Degola et al. (2020), Bisceglie et al. (2020), Dikilitas et al. (2018), Yada and Singh (2013) report that and benzoic acid and benzaldehyde - compounds present in the flavoring evaluated in the present study - in concentrations of 30 to 500 ppm, is a potent inhibitor of seed germination and root growth in different plant species, as well as the germination of conidia in fungi, such as genera Aspergillus, Penicillium and Fusarium. These authors emphasize that while these substances become important for agriculture in the control of invasive plants and pathogenic fungi, it can also be harmful, when used indiscriminately, to germination and development of important plants and fungi for environmental homeostasis.

Table 5 presents the results of cell division indexes and cell alterations of $A$. cepa roots exposed to different concentrations of the almond additive where it was found that the concentrations of 100 and $10 \mu \mathrm{L} / \mathrm{L}$ of the flavoring, in the exposure times 24 and 48 hours, significantly reduced the cell division index, proving cytotoxic to root meristems. 
Research, Society and Development, v. 10, n. 4, e51810414203, 2021

(CC BY 4.0) | ISSN 2525-3409 | DOI: http://dx.doi.org/10.33448/rsd-v10i4.14203

Table 5. Mitotic indices (\%) and Cellular Alteration Indices observed in A. cepa root meristems exposed to artificial almond flavoring, in different concentrations, in 24- and 48-hour exposure.

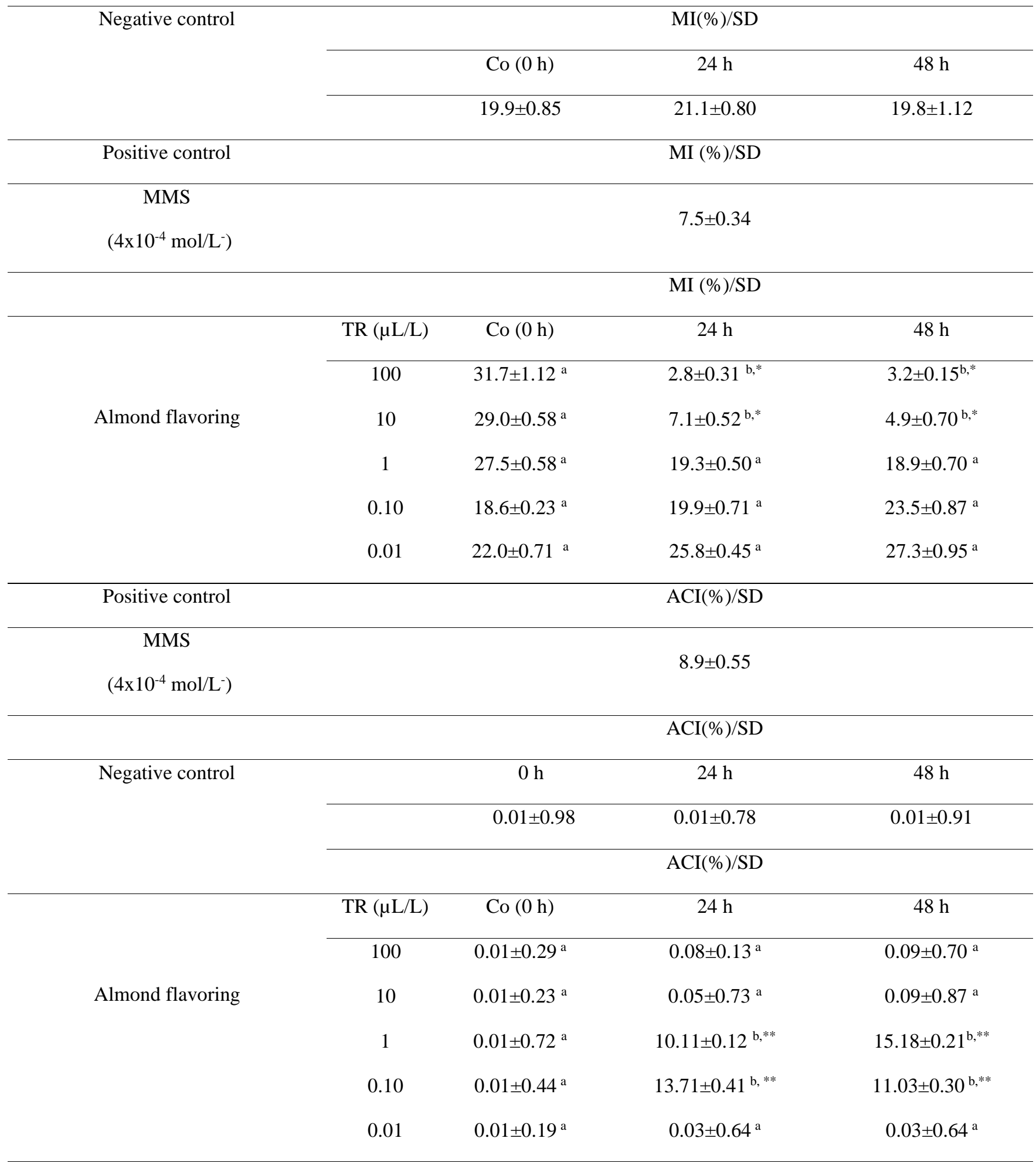

Co: control; MI: mitotic index; ACI: cellular alteration index; TR: treatment; h: hour. MMS: methyl methane sulfonate. Analysis of variance (ANOVA), observed means compared by the Scott-Knott test at 0.05 , using the free BioEstat ${ }^{\circledR}$ software. Different letters indicate significantly different mean values between the exposure times considered ( $\mathrm{Co}-0 \mathrm{~h}, 24 \mathrm{~h}$ and $48 \mathrm{~h}$ ) within the same concentration. Standard deviations reported for each analysis time evaluated for each concentration. *Mitotic index equal to the mitotic index observed for the positive control. **Cellular alteration index equal to the observed change index for the positive control. Source: Authors. 
According to Herrero et al. (2012) and Zilifdar et al. (2012), the significant inhibition of cell division, as observed in the meristem tissues of $A$. cepa roots exposed to concentrations 100 and $10 \mathrm{ug} / \mathrm{L}$ almond additive, is due to cell death due to disturbances, as by the toxic action of chemical substances or compounds, in the cell division kinetics or to chromosomes essential to the cells. Such events, according to Nunes et al. (2016), cause significant reduction in cell turnover and alter the protein synthesis of the tissue or organ where they occur, significantly impairing growth and development in plants and animals.

Unlike the concentration 100 and $10 \mu \mathrm{L} / \mathrm{L}$, the concentrations 1 to $0.01 \mu \mathrm{L} / \mathrm{L}$ of the flavoring in question did not interfere with cellular proliferation in root meristems, since their mitotic indices were similar to those specific exposure times 24 and 48 hours, as well as their respective controls. However, concentrations of 1 to $0.01 \mu \mathrm{L} / \mathrm{L}$, in the 24 and 48 hours of exposure, demonstrated a significant number of prophases in detriment to the other phases of mitosis (Figure 3). Table 3 shows the percentages of each phase of mitosis of meristematic cells from A. cepa roots.

Figure 3. Cell cycle phase indices obtained for the different concentrations of almost flavoring at exposure times 0 hour (Co), 24h and 48 hours. NC: negative control, h: hour.

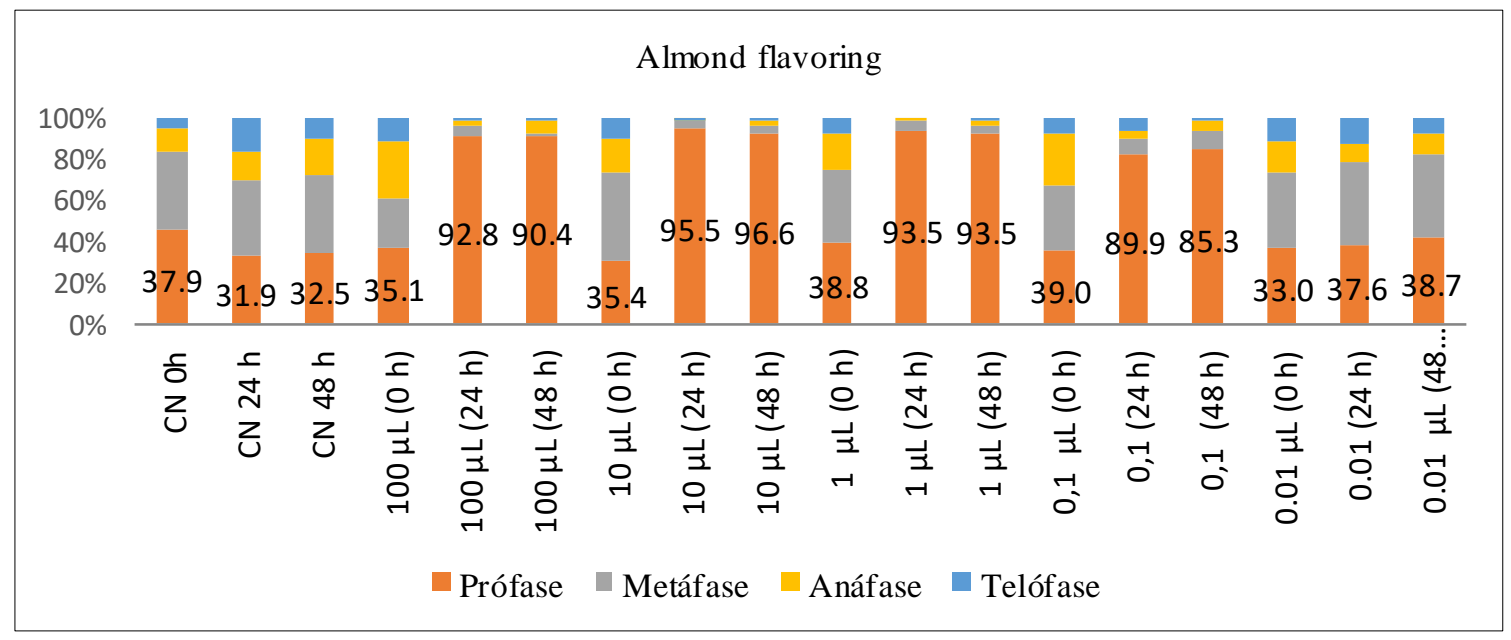

Source: Authors.

This condition suggests aneugenic effect of the concentrations of 1.00 and $0.10 \mu \mathrm{L} / \mathrm{L}$ of the almond additive against the root tips of A. cepa. Guedes et al. (2018) report that the presence of many cells arrested in prophase signals the presence of chemical agents that slow or disrupt the mitotic machinery, causing the cell cycle to occur less frequently or, in fact, to arrest. According to Frâncica et al. (2021), when there is a number of prophases greater than $40 \%$ in relation to the other dividing cells, with an increase in the number of prophases as the exposure time increases, it is suggested the presence of agents that interfere or inhibit the formation of the mitotic spindle, preventing cells from advancing in cell division and continuing the cell cycle.

Therefore, in the same way as the significant inhibition of cell proliferation where most of the cells are in interphase, an expressive number of prophases also impairs tissue growth and cell turnover in plants and animals.

In addition, as described in Table 1 , the concentrations 1 and $0.10 \mu \mathrm{L} / \mathrm{L}$ almond flavoring promoted a significant number of micronuclei, nuclear buds, chromosomal breaks and anaphase bridges, being therefore genotoxic to root meristem cells of $A$. сера. The concentration of $0.01 \mu \mathrm{L} / \mathrm{L}$ of the flavoring did not induce a significant frequency of cellular alterations in the evaluated plant tissues (Figure 4). Figure 4 shows normal cells and abnormal cells with root tips exposed to the almond additive. 
Figure 4. Normal cells and cells with chromosomal and nuclear alterations observed in root meristem cells of A. cepa exposed to different concentrations of the almond flavoring.
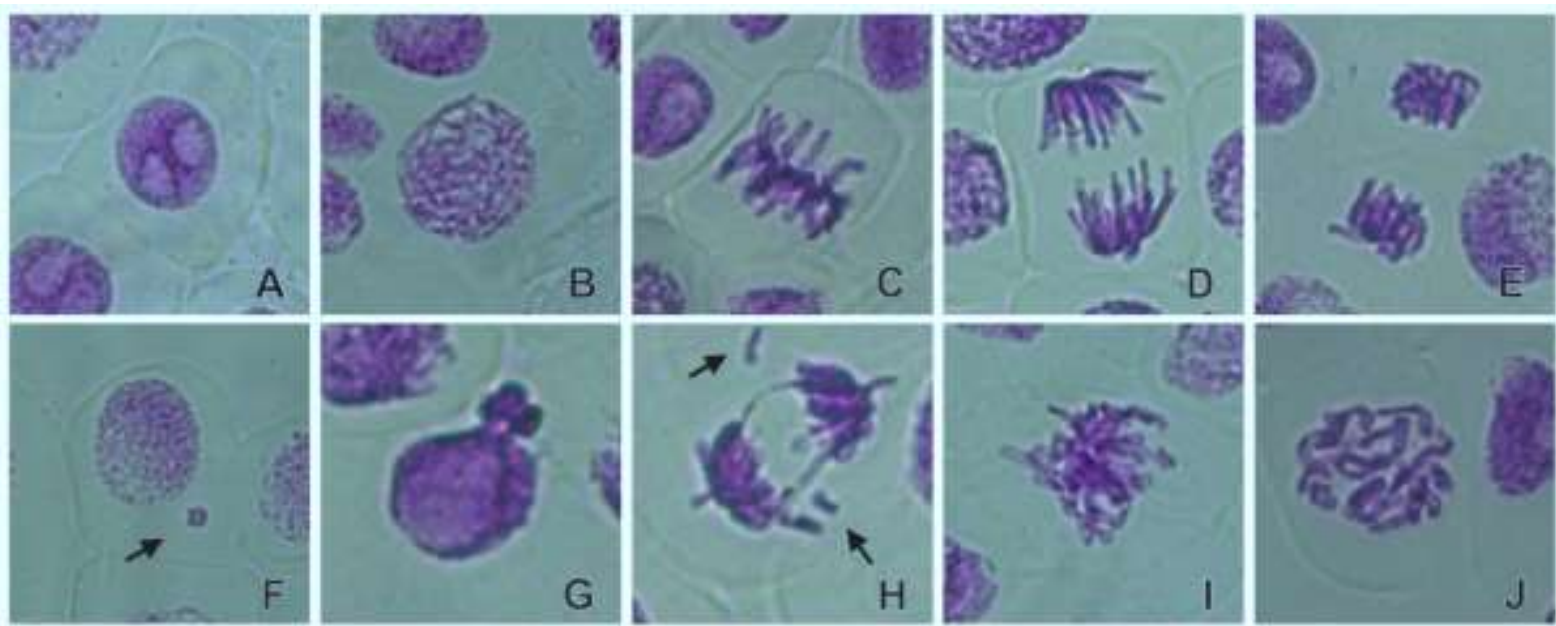

Figure A - interphase with two active regions, Figure B - normal prophase (arrow), Figure C - normal metaphase (arrow), Figure D - normal anaphase (arrow), Figure E - normal telophase (arrow), Figure F - micronucleus (arrow), Figure G - nuclear buds, and Figure H (arrow) chromosomal break and anaphase bridge, I - C-metaphases and J - end of prophase and beginning of formation of a C-metaphase. Source: Authors.

Aissa et al. (2012) report that late chromosomes in anaphase, the anaphase bridges, can cause chromosomal break and/or chromosome loss resulting in cells with different chromosome numbers. Such alterations when in significant frequency cause nuclear instability, giving rise to acentric fragments that, as a result, will form micronuclei at the end of cell division. Considering the principle of cell cycle, which is the formation of identical cells, the production of cells with alteration in the structure and/or chromosome number make cell function impracticable and tend to be eliminated from tissues with normal performance.

Furthermore, Zaineddin et al. (2012) and Queiroz et al. (2013) point out that micronuclei when in expressive presence in tissues in constant cell cycle signal that the tested compounds and/or substances promoted a significant cellular toxicity, a condition that can cause relevant genetic instability in cells. Although genotoxicity is not a measure of carcinogenicity, it is often associated with cancerous processes, since there is a positive correlation between increased frequency of micronuclei and the development of neoplasms in animals.

Demir et al. (2010) found that benzaldehyde caused significant damage to the mitotic spindle and, consequently, the cell division of human peripheral blood cells. In 2008, these same authors verified somatic mutation in Drosophila melanogaster L. wings submitted to benzaldehyde characterizing them as significant cytotoxic and genotoxic agents. In addition, Dikilitas et al. (2018), in concentrations 30 and $60 \mathrm{ppm}$, and Turkoglu (2007), in concentrations 20 to $100 \mathrm{ppm}$, also evaluated benzoic acid in A. сеpa at concentrations of 30 and $60 \mathrm{ppm}$ and found a relevant cytotoxic and aneugenic potential of this compound. Oliveira et al. (2016) verified the cytotoxic and genotoxic potential of saccharin against the meristematic cells of A. cepa roots, and Arif et al. (2013) observed the genotoxic action of this sweetening substance in D. melanogaster larvae at concentrations 100, 150, 200 and $250 \mathrm{mM}$.

Table 5 shows the results of Toxicity of almond flavoring (LC50) by A. salina. Results on A. salina nauplii mortality after exposure to different almond flavoring concentrations for 24 hours revealed mortality in all concentrations tested and mortality was found to be $100 \%$ up to the concentration of $0.39 \mathrm{ppm}$. Mortality increases with the increase of almond flavoring concentration. The $\mathrm{LC}_{50}$ value of almond flavoring were $0.082 \mathrm{ppm}$, demonstrated highly toxic (Figure 5). 
Figure 5. Toxicity of almond flavoring (LC50) by A. salina by A. salina test after 24 hours of exposure.

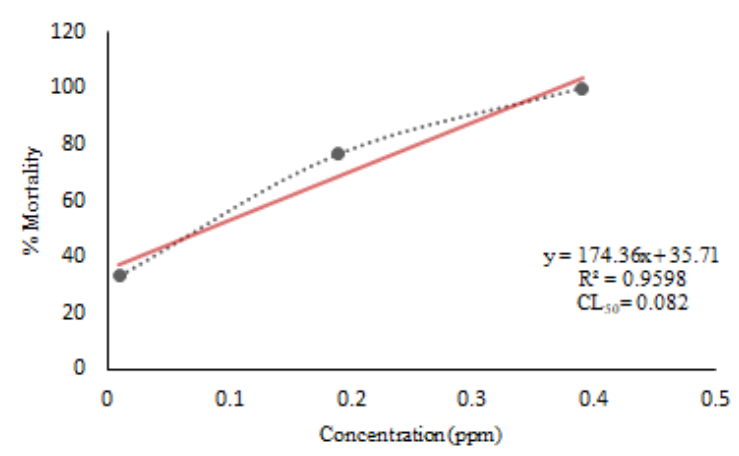

Source: Authors.

The $\mathrm{LC}_{50}$ found in the toxicity test in $A$. salina has a good correlation with the $\mathrm{LD}_{50}$ values found in vivo tests with animals, showing that the test with A. salina can be considered a good test to predict the acute oral toxicity (Parra et al., 2001) and an excellent choice for toxicity investigations of dyes (Sani et al., 2018). In rodents, benzaldehyde, one of the main compounds of almond flavoring, after 14 days of treatment, caused significant hypothermia, reduced motor activity and severe impairment of the central nervous system, evidenced by abnormal gait and tremors (Schrader et al., 2010). In Danio rerio, benzaldehyde promoted apoptosis in embryos and pathological changes, such as increased mortality, inhibition of hatching rates and decreased number of somites. In addition, it caused these organisms pericardial edema and thready pulse due to arrhythmia and cardiac malformation (Bencsik et al., 2018). Furthermore, Saputra et al. (2020) and Martins et al. (2007) reported that saccharin and benzoic acid, in concentrations from 10 to $100 \mathrm{ppm}$, caused high mortality in Daphnia magna $\mathrm{L}$. and promoted a significant damage to the cardiovascular system of D. rerio.

The Kow value obtained in this study for the almond flavoring was $37.1 \pm 1.8$, with logKow of 1.57 , considering a scale from -3 , for highly hydrophilic compounds, to +10 for extremely hydrophobic compounds (Franco and Trapp 2008, Cumming and Rücker 2017). The logKow value of 1.57 of the flavoring solution shows significant affinity of the additive for soil colloids and, relatively, good stability in water, conditions that favor its permanence in the environment.

Wu et al. (2021) conducted a study to evaluate waters receiving industrial effluents and found significant persistence of benzaldehyde and its derivatives in surface waters. Also, benzaldehyde is widely used in fragrances (as in colognes, perfumes and body creams), and has an average of 30 hours in the air. According to Uhde and Schulz (2015) this compound can be transported with dust particles from the atmosphere and later be affixed to the soil by wet and dry deposition, a condition that favors the contamination of surface and underground waters.

The results presented here demonstrated the toxic potential of almond flavoring to different species - which, added to the data in the scientific literature on the adverse effects of benzaldehyde, benzoic acid and saccharin to different organisms raise an alert to the scientific community regarding the release of this additive in the environment. It is expected that data obtained here may assist regulatory agencies to establish limits on the release of industrial effluents consisting of artificial flavorings into the environment. Saccharin, benzaldehyde and benzoic acid are considered by several authors, such as those previously mentioned in this work, as compounds that are potentially toxic to the environment or ecotoxic. Thus, the results brought by the present work show that commercial formulations consisting of these compounds, such as almond flavoring, can be potentially dangerous to different species and the need to establish limits for the release of this additive in the environment is reiterated. 


\section{Conclusion}

The chemical identification detected ethanol (solvent), saccharin, benzaldehyde and benzoic acid. In $L$. sativa and A. cepa, concentrations of 100 and $10 \mu \mathrm{L} / \mathrm{L}$ flavoring caused a reduction in the germination rate and inhibition of root growth. In A. сера, at 24 and 48 hours of exposure, concentrations 100 and $10 \mu \mathrm{L} / \mathrm{L}$ significantly reduced the division of root meristems, and concentrations 1 and $0.10 \mu \mathrm{L} / \mathrm{L}$ induced cellular changes and were aneugenic to plant meristems. The flavoring was highly toxic to A. salina with $\mathrm{LC}_{50}=0.082 \mathrm{ppm}$. By partitioning into saturated solutions of octane and water, the commercial solution of the almond presented a log Kow of 1.37 .

This study will serve as a model for evaluating other flavorings in the environment, as well as arousing the interest of other researchers in evaluating other food flavorings.

\section{Acknowledgments}

The Federal Technological University of Paraná, Campo Mourão Campus

\section{References}

Aissa, A. F., Bianchi, M. L. P., Ribeiro, J. C., Hernandes, L. C., Faria, A. F. \& Mercadante, A. Z. (2012). Comparative study of $\beta$-carotene and microencapsulated $\beta$-carotene: evaluation of their genotoxic and antigenotoxic effects. Food Chemical and Toxicology, 50, 1418-1424. https://doi.org/10.1016/j.fct.2012.02.030

Amchova, P., Kotolova, H. \& Ruda-Kucerova, J. (2015). Health safety issues of synthetic food colorants. Regulatory Toxicology and Pharmacology, 73, 914 922. https://doi.org/10.1016/j.yrtph.2015.09.026

Arif, A. \& Uysal, H. (2013). Examination of the Genotoxic Effects of Various Parabens Used as Food Additives with the Drosophila Wing Spot Test (SMART). Journal of Applied Biological Science, 7, 83-88.

Bencsik, D., Gazsi, G., Urbányi, B., Szende, B., Rácz, G., Véha, A. \& Csenki, Z. (2018). Assessment of subacute genotoxic and histopathological effects of a food flavour ingredient, 4-ethylbenzaldehyde (EBA) on zebrafish (Danio rerio) model. Acta Alimentaria, 47, 245-251. https://doi.org/10.1556/066.2018.47.2.14

Biruk, L. N., Moretton, J., Iorio, A. F., Weigandt, C., Etcheverry, J., Filippetto, J. \& Magdaleno, A. (2017). Toxicity and genotoxicity assessment in sediments from the Matanza-Riachuelo river basin (Argentina) under the influence of heavy metals and organic contaminants. Ecotoxicology Environmental Safety, 135, 302-311. https://dx.doi.org/10.1016/j.ecoenv.2016.09.024

Bisceglie, F., Degola, F., Rogolino, D., Giannelli, G., Orsoni, N., Spadola, G. \& Pelosi, G. (2020). Sisters in structure but different in character, some benzaldehyde and cinnamaldehyde derivatives differentially tune Aspergillus flavus secondary metabolism. Science Report, 10 , 1-14. https://doi.org/10.1038/s41598-020-74574-z

Bom, S.; Jorge, J.; Ribeiro, H. M. \& Marto, J. (2019). A step forward on sustainability in the cosmetics industry: A review. Journal Cleaner Product, 225, 270-290. https://doi.org/10.1016/j.jclepro.2019.03.255

Borrirukwisitsak, S., Keenan, H. E. \& Gauchotte-Lindsay. C. (2012). Effects of salinity, pH and temperature on the octanol-water partition coefficient of bisphenol A. International Journal of Environmental Science and Development, 3, 460. https://doi.org/10.1038/s41598-020-74574-z

Brasil (2007). Ministério da Saúde. Agência Nacional de Vigilância Sanitária. Resolution RDC n.2, of January 15, 2007. Approves the "Resolution of the Collegiate Board of Directors that approves the technical regulation on flavoring additives, which is included as an annex to this Resolution" (in portuguese). http://www.anvisa.gov.br/legis/resol/2007/rdc/02_170107rdc.htm>

Carvalho, S. J. P., Dias, A. C. R., Minamiguchi, M. H., Nicolai, M. \& Christoffoleti, P. J. (2015). Residual activity of six herbicides applied to the soil in the dry season (in Portuguese). Ceres, 59.

Cumming, H. \& Rücker, C. (2017). Octanol-water partition coefficient measurement by a simple 1H NMR Method. ACS Omega, $2,6244-6249$.

Demir, E., Kocaglu, S. \& Kaya, R. (2010). Assessment genotoxic effects of benzyl derivatives by comet assay. Food Chemical and Toxicology, 48,1239-1242. https://dx.doi.org/10.1016/j.ftc.2010.02.016

Dikilitas, S., Tütünoglu, B., Aksoy, Ö. \& Rind, N. A. (2018). The Cytotoxic Effects of Benzoic Acid and Coumarin on Allium cepa var. cepa. Journal of Functional and Environmental Botany, 8, 1-6. http://doi.org/10.5958/2231-1750.2018.00001.X

EFSA. (2012). Scientific opinion on flavouring group Evaluation 20, Revision 4 (FGE.20REV4): Benzyl alcohols, benzaldehydes, a related acetal, benzoic acids, and relates esters from chemical groups 23 and 30. EFSA Journal, 10, 1-140. https://doi.org/10.2903/j.efsa.2012.2994

FAO. Food and Agriculture Organization". Encyclopedia Britannica. (2006). https://www.britannica.com/topic/Food-and-Agriculture-Organization. 
Francica, L. S., Goncalves, E. V., Santos, A. A., Vicente, Y. S., Silva, T. S., Silva, A. P. S., Gonzalez, S., Almeida, P. M., Feitoza, L. L., Bueno, P. A. A., Souza, D. C. \& Peron, A. P. (2021). Antiproliferative, genotoxic and mutagenic potential of synthetic chocolate food flavoring: Toxicity of chocolate food flavoring. Brazilian Journal of Biolology, 82, 223.

Franco, A. \&Trapp, S. (2008). Estimation of the soil-water partition coefficient normalized to organic carbon for ionizable organic chemicals. Environmental Toxicology and Chemistry International Journal, 27, 1995-2004. https://doi.org/10.1897/07-583.1

Gholivand, M. B. \& Ahmadi, F. (2008). Simultaneous determination of trans-cinnamaldehyde and benzaldehyde in different real samples by differential pulse polarography and study of heat stability of trans-cinnamaldehyde. Analytical Letters, 41(18), 3324-3341. https://doi.org/10.1080/00032710802507893

Guedes, C. M., Santos, F. K. S., Silva, T., Soares, A. P., Lima, M. V. L., Oliveira, V. A. \& Peron, A. P. (2018). Cytotoxic and genotoxic potential of Ginkgo biloba L., in industrialized and without-additive forms. Bioscience Journal, 44, 1017-1024. https://doi.org/10.14393/BJ-v34n1a2018-39745

Guerra, M. \& Souza, M. J. (2002) How to observe chromosomes: a guide to techniques in plant, animal and human cytogenetics (in Portuguese). Ribeirão Preto: FUNPEC. 200 p.

Herrero, O.; Martín, J. P. ; Freire, P. F. ; López, L. C. ; Peropadre, A. \& Hazen, M. J. (2012). Toxicological evaluation of three contaminants of emerging concern by use of the Allium cepa test.Mutation Research/Genetic Toxicology and Environmental Mutagenesis, 743, 20-24. https://doi.org/10.1016/j.mrgentox.2011.12.028

Himri, I.; Guaadaoui, A.; Souna, F.; Bouakka, M.; Melhaoui, A.; Hakkoum, A. \& Saalaoui, E. (2013). Toxicity testing of Tartrazine using the nematode Caenorhabditis elegans, brine shrimp larvae (Artemia salina) and KGN Granulosa Cell Line. Journal of Applied Pharmacology Science, 3, 51. https://doi.org/10.7324/JAPS.2013.31110

IFF International Flavors and Fragrances INC. (2017). Sustainability Report. https://www.iff.com/ /media/files/IFF/documents/2017-iff-sustainability-report04-12-18-updated.pdf.

Industryarc. (2021). Flavor \& Fragrances Market - Industry analyses, market size share, Trends, Applications Analyses, Grow and Forecast 2019-2025. https://www.industryarc.com/Research/Flavors-fragrances-Market.

Koche, J. C. (2012). Fundamentos de metodologia cientifica. Vozes.

Leffingwell \& Associates (2015-2020) Flavor \& Fragrances Industry Leaders. http://www.leffingwell.com_10htm.

Marques, G. S. ; Silva, S. I. D. O. D. ; Ferreira, P. M. P. \& Peron, A. P. (2015) Cytotoxic and genotoxic potential of liquid synthetic food flavorings evaluated alone and in combination. Ciência e Tecnologia de Alimentos, 35, 183-188. http://dx.doi.org/10.1590/1678-457X.6596

Martins, J., Teles, L. O. \& Vasconcelos, V. (2007). Assays with Daphnia magna and Danio rerio as alert systems in aquatic toxicology. Environmentl International, 33, 414-425. https://doi.org/10.1016/j.envint.2006.12.006

Matos, L. A., Cunha, A. C., Sousa, A. A., Maranhão, J. P., Santos, N. R., Gonçalves, M. C. M. \& Ferreira-Junior, H. (2017). The influence of heavy metals on toxicogenetic damage in a Brazilian tropical river. Chemosphere, 185, 852-859. https://doi.org/10.1016/j.chemosphere.2017.07.103

Mendes, S. A., Gonçalves, E. V., Frâncica, L. S., Correia, L. B. C., Nicola, J. V. N., Pestana, A. C. Z. \& Peron, A. P. (2020). Quality of Natural Waters Surrounding Campo Mourão, State of Paraná, Southern Brazil: Water Resources Under the Influences from Urban and Agricultural Activities. Water, Air \& Soil Pollution, 231, 1-10. https://doi.org/10.1007/s11270-020-04795-5

Mendes, S., Frâncica, L. S., Gonçalves, É. V., Coleto, L. B., Nicola, J. V. N., Pestana, A. C. Z. \& Peron, A. P. (2021). Prospecting for Phytotoxicity and Enzymatic Modulation of Waters from Springs in the Surroundings of Campo Mourão, State of Paraná, Brazil, in Lactuca sativa L Water, Air \& Soil Pollution, 232, 1-10. https://doi.org/10.1007/s11270-021-05003-8

Nunes, R. D. M., Sales, I. M. S., Silva, S. I., Sousa, J. M. C. \& Peron, A. P. (2017). Antiproliferative and genotoxic effect of food additives with synthetic aroma and flavor, of the same types as natural and artificial. Brazilian Journal of Biology, 77, 50-154. https://doi.org/10.1590/1519-6984.12115

Oliveira, V. M., Oliveira, T. W. N., Damasceno, A. N. C., Oliveira, C. E. S., Medeiros, S. R. A. \& Castro, J. M. (2017). Evaluation of cytotoxic and mutagenic effects of two artificial sweeteners by using eukaryotic test systems. African Journal of Biotechnology, 16, 547-551. https://doi.org/10.5897/AJB2016.15695

Parra, A. L., Yhebra, R. S., Sardiñas, I. G. \& Buela, L. I. (2001). Comparative study of the assay of Artemia salina L. and the estimate of the medium lethal dose (LD50 value) in mice, to determine oral acute toxicity of plant extracts. Phytomedicine, 8, 395-400.

Queiroz, F. M. D., Matias, K. W. D. O., Cunha, M. M. F. D. \& Schwarz, A. (2013). Evaluation of (anti) genotoxic activities of Phyllanthus niruri L. in rat bone marrow using the micronucleus test. Brazilian Journal of Pharmacology Science, 49, 135-148. http://dx.doi.org/10.1590/S1984-82502013000100015.

Ramesh, M. \& Muthuraman, A. (2018). Flavoring and coloring agents: Health risks and potential problems. In: Natural and artificial flavoring agents and food dyes. London: Academic Press, 300p.

Rocha, R. B. R., Peron, A. P. P., Santos, F. K. S., Marques, M. M. M., Sousa, M. E. S., Oliveira, V. A. D. O. \& Nascimento, A. L. D. (2018). Toxic, cytotoxic and genotoxic potential of synthetic food flavoring. Acta Toxicologia Argentina, 26, 65-70.

Rosa, C. S., Veras, K. S., Silva, P. R., Lopes-Neto, J. J., Cardoso, H. L. M., Alves, L. P. L. (2016). Chemical composition and toxicity against Aedes aegypti L. and Artemia salina leach from the essential oil of the leaves of Myrciasylvatica (G. Mey.) DC. Revista Brasileira de Plantas Medicinais, 18 , 19-26. https://doi.org/10.1590/1983-084X/15_006

Sales, I. M. S., Silva, J. M., Moura, E. S. R., Alves, F. D. S, Silva, F. C. C., Sousa, J. M. C. \& Peron, A. P. (2018). Toxicity of synthetic flavorings, nature identical and artificial, to hematopoietic tissue cells of rodents. Brazilian Journal of Biology, 78, 306-310. https://doi.org/10.1590/6984.07716. 
Research, Society and Development, v. 10, n. 4, e51810414203, 2021

(CC BY 4.0) | ISSN 2525-3409 | DOI: http://dx.doi.org/10.33448/rsd-v10i4.14203

Sales, I. M. S., Silva, J. M., Moura, E. S. R., Alves, F. D. S., Silva, F. C. C., Sousa, J. M. C. \& Peron, A. P. (2017). Acute toxicity of grape, plum and orange synthetic food flavourings evaluated in vivo test systems. Food Technology and Biotechnology, 55, 131-137. https://doi.org/10.1590/1519-6984.07716

Sani, Z. M, Abdullahi, I. . L. \& Sani, A. (2018). Toxicity evaluation of selected dyes commonly used for clothing materials in urban Kano, Nigeria. European Journal of Experimental Biology, 8, 26. https://doi.org/10.21767/2248-9215.100067

Silva, T. S., Silva, A. P. S., Santos, A. A., Ribeiro, K. G., Souza, D. C., Bueno, P. A. A. \& Peron, A. P. (2020). Cytotoxicity, Genotoxicity, and Toxicity of Plant Biostimulants Produced in Brazil: Subsidies for Determining Environmental Risk to Non-Target Species. Water, Air \& Soil Pollution, 231. https://doi.org/10.1007/s11270-020-04614-x

Tabrez, S. \& Ahmad, M. (2011). Components of antioxidative system in Allium cepa as the toxicity monitor of trichloroethylene (TCE). Toxicology \& Environmental Chemistry, 93, 73-84. https://doi.org/10.1080/02772248.2010.498375

Teaf, C. M., Teaf, K. W. \& Covert, D. J. (2015). Toxicology \& environmental significance of benzaldehyde. In Annual International Conferences, $21,43$.

Türkoğlu, Ş. (2007). Genotoxicity of five food preservatives tested on root tips of Allium cepa L. Mutation Research, 626 (1-2), 4-14. http://dx.doi.org/10.1016/j.mrgentox.2006.07.006

Uhde, E. \& Schulz, N. (2015). Impact of room fragrance products on indoor air quality. Atmospheric Environmental, 106, 492-502.

Wu, J., Gao, Y., Qin, Y., Li, G. \& An, T. (2021). Photochemical degradation of fragrance ingredient benzyl formate in water: Mechanism and toxicity assessment. Ecotoxicology and Environmental Safety, 211, 111950.

Yadav, K. \& Singh, N. B. (2013). Effects of benzoic acid and cadmium toxicity on wheat seedlings. Chilean Journal of Agricultural Research, 73, 168-174. http://dx.doi.org/10.4067/S0718-58392013000200013

Zaineddin, A. K., Buck, K., Vrieling, A., Geinz, J., Flesch-Janys, D. \& Linseisen, J. (2012). The association between dietary lignans, phytoestrogen-rich foods, and fiber intake and postmenopausal breast cancer risk: a German case-control study. Nutrition and Cancer, 64, 652-665. https://doi.org/10.1080/01635581.2012.683227

Zhao, L., Ortiz, C., Adeleye, A.S., Hu, Q., Zhou, H., Huang, Y. \& Keller, A.A. (2016). Metabolomics to detect response of lettuce (Lactuca sativa) to Cu (OH) 2 nanopesticides: Oxidative stress response and detoxification mechanisms. Environmental Science and Technology, 50, 96979707. https://doi.org/10.1021/acs.est.6b02763

Zilifdar, F., Foto, E., Ertan-Bolelli, T., Yildiz, I., Aki-Yalcin, E. \& Diril, N. (2018). Inhibition of DNA Topoisomerases by a Series of Benzoxazoles and their Possible Metabolites. Letters in Drug Design \& Discovery,15, 1155-1162. https://doi.org/10.2174/1570180815666180124143246 